\title{
Garlic (Allium sativum L.) inhibitory effect on platelet activity induced by different agonists
}

\section{Efecto inhibitorio del ajo (Allium sativum L.) sobre la actividad plaquetaria inducida por diferentes agonistas}

\author{
Roxana Elizabeth González ${ }^{1,2}$, Verónica Carolina Soto ${ }^{3}$, María Mirta Sance ${ }^{4}$, Claudio \\ Rómulo Galmarini ${ }^{1,4,5}$
}

Originales: Recepción: 26/08/2019 - Aceptación: 01/04/2021

\begin{abstract}
Platelets are essential elements of human blood. In addition to their normal role, platelets are involved in causing myocardial infarction, stroke and other thrombotic disorders. Platelet activation in vivo, probably involves a combination of agonists. Garlic has beneficial effects due to its ability to inhibit platelet aggregation and thromboxane formation. The aim of this work was to evaluate the ability of garlic extracts to inhibit platelet aggregation induced by different agonists and their mixtures in different donors. Significant differences were found in platelet aggregation in response to each agonist $(\mathrm{P} \leq 0.05)$. The highest antiaggregatory effect was observed with arachidonic acid and the lowest effect with collagen-arachidonic acid mixture. Interaction effects between donor and agonist (or mixtures) were detected. The study showed the potential of aqueous garlic extracts to prevent platelet aggregation induced by different agonist.
\end{abstract}

\section{Keywords}

Allium sativum L. • Perla INTA cultivar • coagulation • antiaggregatory effect

1 Instituto Nacional de Tecnología Agropecuaria (INTA). Estación Experimental Agropecuaria La Consulta. La Consulta. CP 5567. Mendoza. Argentina. gonzalez.roxana@inta.gob.ar

2 Universidad Nacional de Cuyo. Facultad de Ciencia Exactas y Naturales. Padre Jorge Contreras 1300. Mendoza. Argentina.

3 Universidad Nacional de Cuyo. Facultad de Ciencias Agrarias. CONICET. IBAM. Almirante Brown 500. Chacras de Coria. Luján de Cuyo. M5528AHB. Mendoza. Argentina.

4 Universidad Nacional de Cuyo. Facultad de Ciencias Agrarias. Instituto de Horticultura. Almirante Brown 500. Chacras de Coria. Luján de Cuyo. M5528AHB. Mendoza. Argentina.

5 Consejo Nacional de Investigaciones Científicas y Técnicas (CONICET). Argentina. 


\section{RESUMEN}

Las plaquetas son componentes esenciales de la sangre humana. Además de su rol normal, las plaquetas pueden estar involucradas en procesos que causan infarto de miocardio, apoplejía y otros trastornos trombóticos. La activación plaquetaria in vivo, involucra una combinación de agonistas. El ajo posee efectos beneficiosos debido a su capacidad para inhibir la agregación plaquetaria y la formación de tromboxano. El objetivo fue evaluar la capacidad de extractos acuosos de ajo de inhibir la agregación plaquetaria inducida por diferentes agonistas y sus mezclas en diferentes donantes. Se encontraron diferencias significativas en la agregación plaquetaria en respuesta a cada agonista $(\mathrm{P} \leq 0,05)$. El mayor efecto antiplaquetario se observó con el ácido araquidónico y el menor con la mezcla de colágeno y ácido araquidónico. Se evidenció efecto de interacción entre donante y agonista (o mezclas). El estudio muestra el potencial de los extractos acuosos de ajo para prevenir la agregación plaquetaria inducida por diferentes agonistas.

\section{Palabras clave \\ Allium sativum L. • Perla INTA cultivar • coagulación • efecto antiagregatorio}

\section{INTRODUCTION}

Platelets are key elements of human blood. They play a central role in the process of thrombus formation as well as an important role in atherogenesis and the progression of atherosclerotic lesions (38). When platelets come in contact with damaged or disrupted endothelium, they are activated, changing their shape and releasing their granules content (33). A great number of agents, including adenosine diphosphate, epinephrine, collagen, thrombin, arachidonic acid, antigen-antibody complexes, serotonin and vasopresin, can induce platelet aggregation $(11,13)$. Collagen (C) is an extracellular matrix component, which directly binds to receptors that mediate platelet adhesion inducing activation and aggregation. Two receptors are involved in platelet response to collagen; integrin $\alpha_{2} \beta_{1}$ acts adhering platelets to collagen, allowing platelets to interact with the lower affinity receptor glycoprotein VI, which is mainly responsible for platelet activation (37). Adenosine diphosphate (APD), the first known low molecular weight platelet aggregating agent, is a weak platelet agonist. However, ADP plays an important role in platelet function given that, when released from the platelet dense granules, it amplifies the platelet responses induced by others agonists (18). Arachidonic acid (AA) is considered a key component in haemostasis and thrombosis, since the release of AA can trigger platelet aggregation and prostaglandin synthesis. AA in reaction with cyclooxigenase is converted to thromboxane $A_{2}$, a potent platelet agonist (9). Regarding epinephrine (E), the mechanism by which it induces platelet aggregation is unknown. In some tissues, such as the respiratory epithelium, the activation of the A2AR increases transcellular sodium and chloride cotransport (42).

Several studies have approached platelet aggregation in response to in vitro stimulation of these agonists $(9,22,37,42)$. The fact that platelet aggregation in vivo involves a combination of agonists, is well known. Consequently, to evaluate various agonists simultaneously according to their way of action and their potential synergistic interaction, becomes useful (23). Platelet aggregation is performed to identify abnormal platelet function, to quantify platelet response, and to monitor platelet inhibition through therapeutic drug (29). As an alternative source of natural antithrombotic drugs, the pharmaceutical industry is currently considering garlic to develop better and safer drugs with lower and less side effects. However, the mechanisms by which aqueous garlic extract elicit their antiplatelet effect are not fully known. Garlic (Allium sativum L.) has been used for its antioxidant properties that prevent heart disease including atherosclerosis. Also reduces both plasma cholesterol level and blood pressure (12) and has been recognized as an antiplatelet agent that may contribute to the prevention of cardiovascular disease (34). Raw garlic and some of its preparation like aqueous extracts, garlic oil, aged garlic extract and garlic powder inhibit human platelet aggregation in vitro (17) and in vivo $(4,20,40)$. Many of these physiological effects exerted by garlic are attributed to volatile sulfur-containing flavor compounds, particularly to thiosulfinates, which are responsible for its pungent aroma (24). Allicin (diallylthiosulfinate) is 
the most abundant compound, representing about $70 \%$ of the overall thiosulfinates formed upon crushing garlic cloves (26). It is produced by the interaction of the nonprotein amino acid alliin (+S-allyl-L-cysteine sulfoxide), with the enzyme alliinase (alliin lyase, EC 4.4.1.4) (24). Allicin and other thiosulfinates provide nearly all the antiplatelet activity of raw garlic homogenates in whole blood aggregometry (27). Variability in antiplatelet activity exerted by garlic cultivars belonging to different argentine ecophysiological groups using collagen as agonist has previously been described by our group (15). Perla INTA has the highest organosulfur levels, pungency and in vitro antiplatelet activity, being the most suitable garlic cultivar to obtain pharmacological products (15). In vitro platelet aggregation can be assayed with an electrical impedance aggregometer using different agonist and several donors. Results may exhibit large variances both among and within platelet donors. Consequently, it is desirable to use an experimental design with several agonists and donor's in order to make their results comparable.

Therefore, this study was conducted to determine the in vitro antiplatelet activity of aqueous extract of Perla INTA cultivar induced by different agonists and their mixtures.

\section{MATERIALS AND METHODS}

\section{Chemicals}

All chemicals used were of analytical grade. Collagen $\left(1 \mathrm{mg} \mathrm{mL}^{-1}\right)$ was purchased from Chrono-log Corp, adenosine diphosphate, arachidonic acid and epinephrine were obtained from Helena Laboratory (Beaumont, TX, USA). Stock solutions of each agonist were prepared in deionized water and mixed gently until completely dissolved the following concentrations: $10 \mu \mathrm{M}$ ADP, 0,5 mM AA, epinephrine $50 \mu \mathrm{M}$. These solutions were stored at $-20{ }^{\circ} \mathrm{C}$, except for the collagen solution, which was stored at $4{ }^{\circ} \mathrm{C}$.

\section{Preparation of aqueous garlic extracts}

Fresh garlic bulbs of Perla INTA cultivar were chosen from the germplasm collection of INTA La Consulta, Mendoza, Argentina. The bulbs were peeled and blended for $1 \mathrm{~min}$ in deionized water $(1: 10 \mathrm{w} / \mathrm{v})$. The aqueous garlic extract was collected, filtered and kept at room temperature for 15 min to allow enzymatic hydrolysis of the flavor precursors. After that, the extracts were kept frozen at $-80^{\circ} \mathrm{C}$.

\section{Aqueous garlic extracts characterization}

The characterization of Perla INTA aqueous garlic extract was carried out according to their flavor precursor levels, thiosulfinates, allicin content, and pungency as previously described González et al. (2009).

\section{Platelet aggregation}

Platelet aggregation was measured in vitro using a whole blood electrical impedance aggregometer (10). Blood was collected from nine non-smoker healthy donors (5 women, 4 men), between 26-45 years old, who had no any previous disease and had not taken aspirin or any medication, and all had given informed consent. They also had abstained from eating Alliums or other known platelet-inhibitory food or beverages in the previous 2 weeks, for at least 7 days prior to venipuncture. A complete blood count, biochemical analysis and the clotting time was carried out following the Ivy method. Clotting times less than 9.5 minutes were considered normal.

Blood samples were collected by venipuncture (Hematology Service, Central Hospital, Mendoza, Argentina) in tubes containing sodium citrate anticoagulant (3.8\%, 1 vol of anticoagulant per 9 vol of blood). Afterward,blood samples were diluted in equal volume of TRIS buffered saline (TBS, pH 7.4) and vortexed. The diluted blood was maintained at room temperature during the experiment and used within $2 \mathrm{~h}$ of donation.

Aliquots of $1 \mathrm{~mL}$ of blood/TBS were incubated for $3 \mathrm{~min}$ at $37^{\circ} \mathrm{C}$, then a dose of aqueous garlic extract was added and platelet aggregation was induced by the addition of different agonists or their mixtures. Changes in the impedance was recorded over $6 \mathrm{~min}$. The change in impedance is proportional to the amount of platelet aggregation. All treatments were eval- 
uated with each donor's blood four times. In vitro antiplatelet activity (AAI) was expressed as percentage of inhibition of platelet aggregation, compared to control samples prepared in the same way but without adding aqueous garlic extract. The control is considered as $100 \%$ the aggregation or $0 \%$ the inhibition for each agonist.

Table 1 shows agonists concentrations prepared as described Bordia et al. (1996); Soloviev et al. (1999); Rahman and Billington, (2000). Based on previous results a concentration of $7 \mathrm{mg}$ of aqueous garlic extract per $\mathrm{mL}$ of blood was chosen for platelet aggregations reactions (15). This concentration is equivalent to a daily consumption of 1 clove (1.5 g of garlic for a person weighing $70 \mathrm{~kg}$ ) (43).

Table 1. Concentration of stock solutions of each agonist and their mixtures.

Tabla 1. Concentración de las soluciones stock de cada agonista y sus mezclas.

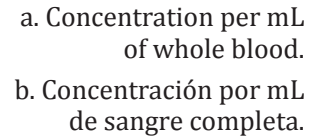

\begin{tabular}{|l|l|}
\hline Agonist & Concentration $^{\mathrm{a}}$ \\
\hline Collagen & $1 \mu \mathrm{g} / \mathrm{mL}$ \\
Arachidonic acid & $0.5 \mathrm{mM}$ \\
Adenosine diphosphate & $10 \mu \mathrm{M}$ \\
Epinephrine & $50 \mu \mathrm{M}$ \\
\hline Mixtures & $1 \mu \mathrm{g} / \mathrm{mL}+0.5 \mathrm{mM}$ \\
\hline Collagen + Arachidonic acid & $1 \mu \mathrm{g} / \mathrm{mL}+10 \mu \mathrm{M}$ \\
Collagen + Adenosine diphosphate & $1 \mu \mathrm{g} / \mathrm{mL}+50 \mu \mathrm{M}$ \\
Collagen + Epinephrine & $10 \mu \mathrm{M}+50 \mu \mathrm{M}$ \\
\hline Adenosine diphosphate + Epinephrine
\end{tabular}

\section{Statistical analysis}

Values were expressed as means \pm SEM. Data were analyzed by analysis of variance (ANOVA) to test the significant differences. Means were compared using Tukey's test. The results were considered significant at $\mathrm{P} \leq 0.05$ unless specified otherwise. Statistical analysis was performed using the software STATISTICA for Windows 6.0. Means of each treatment were compared by least significant difference (LSD) test; $\mathrm{P} \leq 0.05$ were considered to be significant.

\section{RESULTS}

None of the donors included in the assay showed a value of impedance higher than $5 \Omega$ in platelet aggregation induced by ADP. Consequently, this agonist did not cause a significant aggregation in the respective samples. A similar behavior was observed with epinephrine.

Inhibition percentage in platelet aggregation showed significant differences (figure 1, page 50) among different agonists as well as among their combinations. The inhibitory effect on platelet aggregation induced by collagen ranged between $22.5-100 \%$. After adding collagen before aggregation onset, aggregation slopes showed a delay of about $60 \mathrm{~s}$ or more, then followed by a steady increase in aggregation. This delay was greater than control samples when garlic extract was added (data no shown).

Antiplatelet aggregation, when AA was used, ranged between 75.7-100\%. The aggregation slopes showed a monophasic aggregation response to AA.

On the other hand, antiplatelet effects exerted by Perla INTA aqueous extract were studied by using different agonist mixtures. When a collagen-AA mixture was used as platelet agonist, antiplatelet activity ranged between 3.84-26\%. In addition, in vitro Perla INTA aqueous extract suppressed platelet aggregation induced by collagen-epinephrine and ADP-epinephrine induced human platelet in a wide range, $10.23-48.48 \%$ and $20-80 \%$, respectively. Significant synergistic interaction was observed with collagen in combination with epinephrine, AA and ADP, and ADP in combination with epinephrine when added simultaneously at the selected concentration. Thus, higher impedance values were observed when aggregation was induced by two agonists combination (figure 2, page 50). 


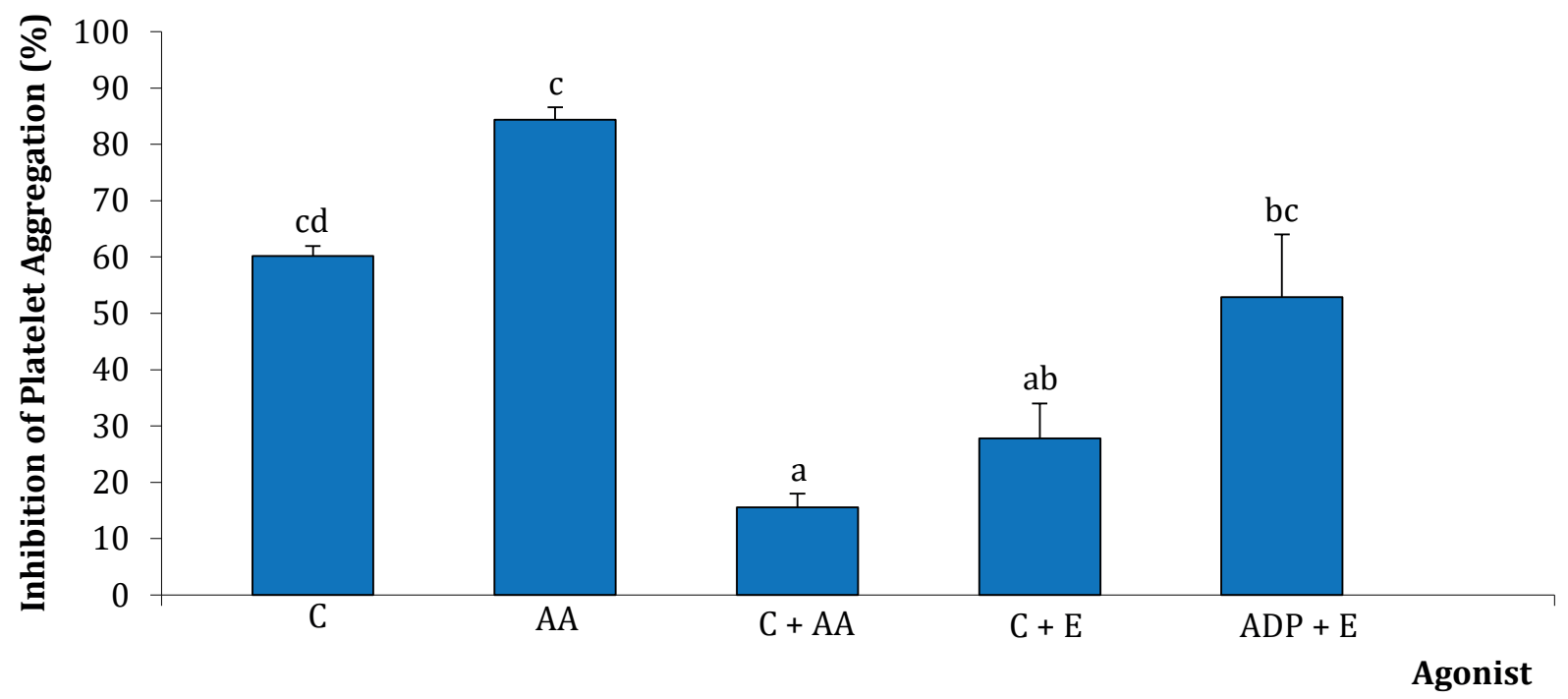

Bars represents means \pm SD ( $n=9)$. Different letters indicate significantly different according to Tukey test (P $\leq 0.05)$. ADP: Adenosine diphosphate, E: Epinephrine, C: Collagen, AA: Arachidonic acid.

Barras representan valores promedio \pm SD $(n=9)$. Letras distintas indican diferencias significativas según test Tukey HSD a P $\leq 0,05$. ADP: Adenosina difosfato, E: Epinefrina, C: Colágeno, AA: Ácido araquidónico.

Figure 1. In vitro inhibition of platelet aggregation exerted by Perla INTA aqueous extracts on platelet aggregation induced by different agonists and their mixtures.

Figura 1. Inhibición de la agregación plaquetaria in vitro ejercida por extractos acuosos de Perla INTA sobre la agregación inducida por diferentes agonistas y sus mezclas.

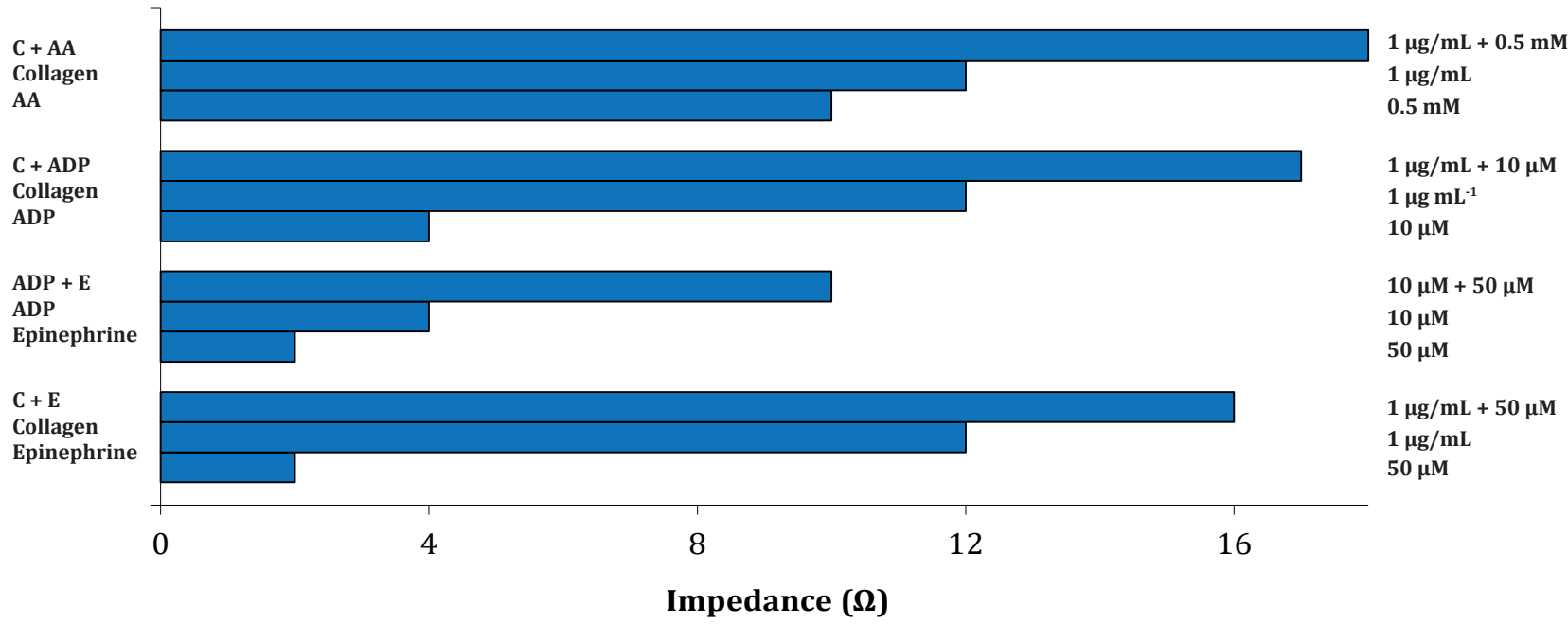

Values at right of bars indicate the concentrations of agonists used. ADP: Adenosine diphosphate, E: Epinephrine, C: Collagen, AA: Araquidonic acid. Valores a la derecha de cada barra indican las concentraciones de agonistas usadas. ADP: Adenosina difosfato, E: Epinefrina, C: Colágeno, AA: Ácido araquidónico.

Figure 2. Aggregation platelet in vitro: synergistic effect exerted by different combinations of agonists.

Figura 2. Agregación plaquetaria in vitro: efecto sinérgico ejercido por diferentes combinaciones de agonistas. 
In general, the antiaggregatory effect showed by Perla INTA aqueous extract on platelet aggregation induced by paired of agonists were minor than antiaggregatory effects observed when platelet aggregation was induced by each agonist alone (figure 1, page 50).

Taking into account average antiplatelet activity of all agonists and mixtures used, this biological activity varied between $18.51 \% \pm 2.43$ and $84.40 \% \pm 2.15$. The highest antiaggregatory effect was observed with AA and the lowest effect with collagen-AA mixture. ANOVA analysis revealed an interaction effect between donor and agonist (or mixtures) at $\mathrm{P} \leq 0.05$ (table 2). ANOVA analysis of donor, agonist and their interaction resulted in 15.2\%, $54.74 \%$ and $26.2 \%$ of variation to the AAI in this study, respectively, indicating that agonist was the main factor determining AAI, and that donor and donor and agonist interaction, played a minor role. There were not significant differences in platelet aggregation inhibition response between women and men.

Table 2. ANOVA table of in vitro antiplatelet activity variation due to donor, agonist, and their interaction.

Tabla 2. Tabla de ANOVA de la actividad antiplaquetaria in vitro por donador, agonista e interacción.

\begin{tabular}{|l|l|l|l|l|l|}
\hline \multicolumn{1}{|c|}{ Source } & d.f & \multicolumn{2}{|c|}{ Sum of square } & F-value & P>F \\
\hline Donor & 2 & 6929.9 & $(15.2 \%)$ & & \\
Agonist & 4 & 24945 & $(54.74 \%)$ & 59.651 & 0.0000 \\
Donor x agonist & 8 & 11951.8 & $(26.2 \%)$ & 107.36 & 0.0000 \\
Error & 30 & 1742.6 & $(3.84 \%)$ & 25.720 & 0.0000 \\
Total & 44 & 45559.3 & $(100 \%)$ & & \\
\hline
\end{tabular}

The chemical profile of the main organosulfur compound present in Perla INTA aqueous garlic extract is shown in table 3. Alliin was the most abundant ACSO, representing more than $70 \%$ of the total content of ACSOs, whereas isoallin content was nearly to $23 \%$ and methiin content represented less than $10 \%$. Also, this cultivar showed high levels of thiosulfinates, allicin, and pungency.

Table 3. S-alk(en)yl-L-cysteine sulfoxides (ACSOs), thiosulfinates, allicin, and pungency of Perla INTA garlic cultivar.

Tabla 3. S-alq(en)yl-L-cisteín sulfóxidos (ACSOs), tiosulfinatos, allicina y pungencia del cultivar Perla INTA.

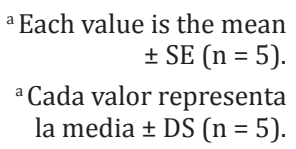

\begin{tabular}{|l|l|c|}
\hline \multicolumn{2}{|c|}{ Variables } & Concentration \\
\hline \multirow{3}{*}{ ACSOs (mg.g $\mathbf{- 1}$ fw) } & Alliin & $21.83 \pm 1.33^{\mathrm{a}}$ \\
\cline { 2 - 3 } & Methiin & $1.53 \pm 0.09$ \\
\cline { 2 - 3 } & Isoalliin & $6.87 \pm 0.32$ \\
\cline { 2 - 3 } & Total & $30.22 \pm 0.58$ \\
\hline Total thiosulfinates (mM\%g fw) & $4.45 \pm 0.1$ \\
\hline Allicin (mg/g fw) & $5.04 \pm 0.1$ \\
\hline Pungency $(\boldsymbol{\mu M o l} / \mathbf{g} \mathbf{f w})$ & $79.86 \pm 1.83$ \\
\hline
\end{tabular}

\section{Discussion}

Under pathological conditions, platelets may become more proadhesive/procoagulant, which leads platelets to adhere to an injured area, and to subsequently release a lot of active constituents inducing plug formation (16). For that reason, antiplatelet therapy is used as a strategy to prevent vascular thrombosis and vascular disorders. Several researchers have shown that garlic and their sub products have in vivo $(1,2,8,44)$ and in vitro $(7,28,35)$ antiplatelet activity. These studies have involved the use of collagen, ADP, AA or epinephrine 
as agonists, but not their combinations. In vivo, more than one agonist and different combinations are involved in platelet activation. Therefore, the study of the antiplatelet effect of aqueous garlic extracts over platelet activity induced by different agonists and their combinations was considered of great contribution to the understanding of the factors involved in this activity. Two types of aggregation can be distinguished in vitro: primary aggregation that is reversible and occurs without the release reaction and secondary aggregation that is irreversible and is associated with the release reaction (36). The reversibility of platelet aggregation induced by each dose of agonists included in this study was assessed from the shape of aggregation tracings. A monophasic curve indicating irreversible aggregation was observed with all the agonist and the combinations evaluated. We found that when platelet aggregation was induced by ADP or epinephrine, the aggregation induced was lower than $40 \%$ and $30 \%$ respectively. Similar results have been reported $(6,14,25)$. Mammalian platelets vary widely in their responses to epinephrine, in part due to they can act via excitatory $\alpha$ receptors and inhibitory $\beta$ receptors (41). Some people have reduced platelet responsiveness to epinephrine due to the lack of these receptors (39). This fact might explain the results obtained in our work. On the other hand, when these agonists were used in combination, a synergistic effect was observed. This was evidenced by higher responses than the expected for ADP or epinephrine alone. As it has been previously reported by other authors $(19,36)$.

Regarding collagen, we found that a concentration of $1 \mu \mathrm{g} \mathrm{mL}^{-1}$ induces of $100 \%$ of platelet aggregation in vitro. In addition, we observed that the concentration of Perla INTA aqueous garlic extract used inhibited the platelet aggregation induced by this agonist. Aqueous garlic extracts contain mainly allicin (26). Allicin easily go through cellular membranes and can react with different sulfhydryl (SH)-containing proteins blocking their free sulfhydryl residues (30). We propose that the antiplatelet effect of Perla INTA aqueous garlic extract is due, at least partially, to the inhibition of collagen binding to specific receptors on platelet surface. Consequently, platelet adhesion and platelet activation could be inhibited. This results are in agreement with Manaster et al (2009), who demonstrated that allicin inhibit agonist-induced washed platelet activation via inhibition of platelet signaling. According to Baghalian et al. (2005) the minimum allicin content to ensure pharmaceutical and economic viability of garlic should be $4.5 \mathrm{mg} \mathrm{g}^{-1} \mathrm{fw}$. The higher level of allicin present in this cultivar could be taken as an opportunity to elaborate pharmacological products based on its healthbenefit quality.

A monophasic curve in response to a concentration of $0.5 \mu \mathrm{M}$ of AA was obtained. Both aqueous and organic garlic extracts have been found to inhibit several steps of the AA-cascade in platelets (3). Moreover, garlic extracts inhibit incorporation of labeled AA into platelet phospolipids and inhibit AA-metabolizing enzymes in platelets (15). Ali (1995) showed that raw garlic inhibited cyclooxygenase activity non-competitively and irreversibly. Our results confirm these observations. The highest antiaggregatory effects exerted by Perla INTA aqueous extract were observed when AA was used as agonist.

Platelet aggregation in vivo probably involves a combination of agonists, being collagen more important at the beginning, thrombin becomes important later on, and with other agonists in different mixtures throughout (19). Platelets exhibit diverse responses, including shape change, aggregation, and secretion in response to a variety of agonists. These agonists differ in their intrinsic ability to produce the effects on physiological responses by platelet $(14,21)$. The degree of inhibition depends on the potential activity of each platelet agonist used in the present work. Perla INTA aqueous extract strongly inhibited platelet aggregation induced by a strong agonist like collagen and also by AA. However, the antiaggregatory effect was lower when the aggregation was induced by collagen together with AA. These results demonstrate the synergistic interaction exerted for the combination of agonists used. These results are in agreement with those reported by Razi et al (2005) and Huang and Detwiler (1981), who showed the potentiated response to platelet aggregation in combination of collagen and AA, and epinephrine. The synergism between the different platelet agonists increases platelet aggregations. Full platelet aggregation can also be induced by the simultaneous addition of subthreshold levels of platelet stimuli, which fail to induce platelet aggregation on their own merit (21). 
Other important aspect that was evaluated was the influence of donor, agonist and their interaction. Although, the analysis revealed an interaction effect between donor and agonist, the type of agonist was the main factor determining of in vitro antiplatelet activity. These results were consistent with previous reports that showed that the response of platelets to agonists has a large inter-individual variability within the population $(31,32)$.

\section{CONCLUSION}

This study reveals the potential antiaggregatory effect of Perla INTA aqueous garlic extract, when this activity is induced by different agonists and their mixtures. Several mechanisms are involved in this inhibitory effect, and they include the modification of platelet membrane, a direct inhibitory effect on the AA metabolism and lipoxygenase enzyme and inhibition of calcium mobilization. The modification of platelet membrane inhibits the signaling pathway and consequently the platelet activation and platelet adhesion. When enzymes involved in several steps of AA-cascade are inhibited, endoperoxides intermediates are not converted to prostanglandins and thromboxane $\mathrm{B}_{2}$ which are potent platelet aggregators. Furthermore, a synergistic effect was evidenced. This aspect is important since the therapeutic effect of antiplatelet herbal drugs can be affected. However, the biochemical basis of these synergistic responses needs further exploration.

\section{REFERENCES}

1. Ali, M. 1995. Mechanism by garlic (Allium sativum) inhibits cyclooxygenase activity. Effect of raw versus boiled garlic extract on the synthesis of prostanoids. Prostaglandins Leukot Essent Fatty Acids. 53:397-400.

2. Ali, M.; Thomson, M.; Afzal, M. 2000. Garlic and onions: their effect on eicosanoid metabolism and its clinical relevance. Prostaglandins Leukot Essent Fatty Acids. 62(2): 55-73.

3. Allison, G.; Lowe, G.; Rahman, K. 2006. Aged garlic extract and its constituents inhibit platelet aggregation through multiple mechanisms. J. Nutr. 136: 782S-788S.

4. Ansary, J.; Forbes-Hernández, T. Y.; Gil, E.; Cianciosi, D.; Zhang, J.; Elexpuru-Zabaleta, M.; Simal Gandara, J.; Giampieri, F; Battino, M. 2020. Potential health benefit of garlic based on human intervention studies: a brief overview. Antioxidants. 9:619.

5. Baghalian, K.; Ziai, S.; Naghavi, M.; Badi, H.; Khalighi, A. 2005. Evaluation of allicin content and botanical traits in Iranian garlic (Allium sativum L.) ecotypes. Scientia Horticulturae. 103: 155-166.

6. Banga, H.; Simons, E.; Brass, L.; Rittenhouse, S. 1986. Activation of phospholipases A and C in human platelet exposed to epinephrine: role of glycoproteins Iib/IIIa and dual role of epinephrine. Proc Natl Acad Sci of the USA. 83:3E-6E.

7. Beretta, H. V.; Bannoud, F.; Insani, M.; Berli, F.; Hirschegger, P.; Galmarini, C. R.; Cavagnaro, P. F. 2017. Relationships between bioactive compound content and the antiplatelet and antioxidant activities of six Allium vegetable species. Food Technol. Biotechnol. 55(2): 266-275.

8. Bordia, T.; Mohammed, N.; Thomson, M.; Ali, M. 1996. An evaluation of garlic and onion as antithrombotic agents. Prostaglandins Leukot Essent Fatty Acids. 54(3): 183-6.

9. Capurso, A.; Capurso, C. 2020. Hemostasis and thrombosis. Principles of nutrigenetics and nutrigenomics. In: De Caterina, R.; Martinez J. A.; Kohlmeier M. (Ed.) Principles of Nutrigenetics and Nutrigenomics. Academic Press. 361-369.

10. Cardinal, D.; Flower, R. 1980. The electronic aggregometer: a novel device for assessing platelet behavior in blood. J Pharmacol Methods. 3: 135-158.

11. Choi, J. L.; Li, S.; Han, J. Y. 2014. Platelet function tests: a review of progresses in clinical application. BioMed Research International. ID 456569. doi:10.1155/2014/456569

12. El-Saber Batiha, G.; Magdy Beshbishy, A.; Wasef, L.; Elewa, Y. H. A.; Al-Sagan, A.; Abd El-Hack, M. E.; Taha, A. E.; Abd-Elhakim, Y.; Prasad Devkota, H. 2020. Chemical constituents and pharmacological activities of garlic (Allium sativum L.): a review. Nutrients. 12(3): 872.

13. Estevez, B.; Du, X. 2017. New concepts and mechanisms of platelet activation signaling. Physiology. 32(2): 162-177.

14. Filkova, A. A.; Martyanov, A. A.; Garzon Dasgupta, A. K.; Panteleev, M. A.; Sveshnikova, A. N. 2019. Quantitative dynamics of reversible platelet aggregation: mathematical modelling and experiments. Scientific Reports. 9: 6217.

15. González, R.; Soto, V.; Sance, M.; Camargo, A.; Galmarini, C. 2009. Variability of solids, organosulfur compounds, pungency and health-enhancing traits in garlic (Allium sativum L.) cultivars belonging to different ecophysiological groups. J. Agric. Food Chem. 57: 10282-10288.

16. Hirsch, G. E.; Nazário Viecili, P. R.; Almeida, A. S.; Nascimento, S.; Garcez Porto, F.; Otero, J.; Schmidt, A.; Da Silva, B.; Migliorini Parisi, M.; Zeni Klafke, J. 2017. Natural products with antiplatelet action. Current pharmaceutical design. 23: 1-19. 
17. Hosono, T.; Sato, A.; Nakaguchi, N.; Ozaki-Masuzawa, Y.; Seki, T. 2020. Diallyl trisulfide inhibits platelet aggregation through the modification of sulfhydryl groups. J. Agric. Food Chem. 68: 1571-1578.

18. Hosseinzadegan, H.; Tafti, D. K. 2017. Mechanisms of platelet activation, adhesion and aggregation. Thromb Haemost Res. 1(2): 1008.

19. Huang, E.; Detwiler, T. 1981. Characteristics of the synergistic actions of platelet agonists. Blood. 57: 685-691.

20. Irfan, M.; Kim, M. K.; Kwon, H. W.; Rhee, M. H.; Kim, H. K. 2018. Antiplatelet effects of garlic and chitosan: a comparative study between fermented and non-fermented preparations. Biomedical Science Letters. 24: 280-284.

21. Kamath, S.; Blann, A.; Lip, G. 2001. Platelet activation: assessment and quantification. Eur Heart J. 22: 1561-1571.

22. Koessler, J.; Schwarz, M.; Weber, K.; Etzel, J.; Koessler, A.; Boeck, M.; Kobsar, A. 2017. The role of adenosine diphosphate mediated platelet responsiveness for the stability of platelet integrity in citrated whole blood under ex vivo conditions. PLoS ONE. 12(11): e0188193.

23. Koltai, K.; Kesmarky, G.; Feher, G.; Tibold, A.; Toth, K. 2017. Platelet aggregometry testing: molecular mechanisms, techniques and clinical implications. Int. J. Mol. Sci. 18(8): 1803.

24. Lancaster, J.; Boland, M. 1990. Flavor Biochemistry. In: Rabinowitch, H.; Brewster, J. (Eds.) Onions and Allied Crops. CRC Press: Boca Raton, Philadelphia. 33-72.

25. Lanza, F.; Beretz, A.; Stierle, A.; Hanau, D.; Kubina, M.; Cazenave, J. 1988. Epinephrine potentiates human platelet activation but is not aggregating agent. Am J Physiol. 255: H1276-H1288.

26. Lawson, L.; Wood, S.; Hughes, B. 1991. HPLC Analysis of allicin and other thiosulfinates in garlic clove homogenates. Planta Med. 57: 263-270.

27. Lawson, L.; Ramson, D.; Hughes, B. 1992. Inhibition of whole blood platelet aggregation by compounds in garlic clove extracts and commercial garlic preparations. Thromb Res. 65:141-156.

28. Legnani, C.; Frascaro, M.; Guazzaloca, G.; Ludovici, S.; Cesarano, G.; Coccheri, S. 1993. Effects of a dried garlic preparation on fibrinolysis and platelet aggregation in healthy subjects. Arzneimittelforschung. 43: 119-122.

29. Manaster, Y.; Shenkman, B.; Rosenberg, N.; Savion, N. 2009. Allicin and disulfiram enhance platelet integrin $\alpha I I b \beta 3$-fibrinogen binding. Thromb Res. 124: 477-482.

30. Miron, T.; Rabinkov, A.; Mirelman, D.; Wilchek, M.; Weiner, L. 2000. The mode of action of allicin: its ready permeability through phospholipid membranes may contribute to its biological activity. Biochimt Biophys Acta. 1463: 20-30.

31. Orme, R.; Judge, H.; Storey, R. 2017. Monitoring antiplatelet therapy. Semin Thromb Hemost. 43(03): 311-319.

32. Panzer, S.; Hocker, L.; Koren, D. 2006. Agonists-induced platelet activation varies considerably in healthy male individuals: studies by flow cytometry. Ann Hematol. 85: 121-125.

33. Periayah, M. H.; Halim, A. S.; Mat Saad, A. Z. 2017. Mechanism action of platelets and crucial blood coagulation pathways in hemostasis. Int J Hematol Oncol Stem Cell Res. 11(4): 319-327.

34. Quesada, I.; De Paola, M.; Torres-Palazzolo, C.; Camargo, A.; Ferder, L.; Manucha, W.; Castro, C. 2020. Effect of garlic's active constituents in inflammation, obesity and cardiovascular disease. Curr Hypertens Rep. 22: 6.

35. Rahman, K.; Billington, D. 2000. Dietary supplementation with aged garlic extract inhibits ADPinduced platelet aggregation in humans. J. Nutr. 130: 2662-2665.

36. Razi, M.; Butt, I.; Aslam, M.; Hameed, W.; Ashraf, R.; Effendi, S. 2005. Dose response relationships of different reagents for platelet aggregation. Pak J. Physiol. 1: 11-14.

37. Roberts, D.; McNicol, A.; Bose, R. 2004. Mechanism of collagen activation in human platelets. J. Biol. Chem. 19:1 9421-19430.

38. Sachs, L.; Denker, C.; Greinacher, A.; Palankar, R. 2020. Quantifying single-platelet biomechanics: An outsider's guide to biophysical methods and recent advances. Res Pract Thromb Haemost. 4(3): 386-401.

39. Scrutton, M.; Clare, K.; Hutton, R.; Bruckdorfer, K. 1981. Depressed responsiveness to adrenaline in platelets from apparently normal human donors: a familiar triat. Br J Haematol. 49: 303-314.

40. Shafiekhani, M.; Faridi, P.; Kojuri, J.; Namazi, S. 2016. Comparison of antiplatelet activity of garlic tablets with cardio-protective dose of aspirin in healthy volunteers: a randomized clinical trial. Avicenna J Phytomed. 6(5): 550-557.

41. Soloviev, M.; Okazaki, Y.; Harasaki, H. 1999. Whole blood platelet aggregation in humans and animals: a comparative study. J Surg Res. 82: 180-187.

42. Spalding, A.; Vaitkevicius, H.; Dill, S.; Mackenzie, S.; Schmaier, A.; Lockette, W. 1998. Mechanism of epinephrine induced platelet aggregation. Hypertension. 31: 603-607.

43. Vazquez-Prieto, M.; González, R.; Renna, N.; Galmarini, C.; Miatello, R. 2010. Aqueous garlic extracts prevent oxidative stress and vascular remodeling in an experimental model of metabolic syndrome. J. Agric. Food Chem. 58: 6630-6635.

44. Vilahur, G.; Badimon, L. 2013. Antiplatelet properties of natural products. Vascular Pharmacol. 59(3-4): 67-75.

\section{ACKNOWLEDGMENTS}

We thank the Hematology Service Central Hospital, Mendoza, Argentina, for their kind cooperation. This work was supported by grants from INTA 2019-PD-E7-I152-001. 